\title{
Right of Aged Persons to Live with Dignity: A Socio-Legal Perspective
}

\author{
Ujwala Bendale, Vidya Dhere
}

\begin{abstract}
Modernisation and globalisation has been a boon in developing India to be a smart country technologically but few concepts of the Constitution no longer meets the essence of time and the needs of Aged persons to live with dignity.This article is an attempt to pendown the social and legal problems of aged persons to live with dignity and deprivation of their basic rights and as well it is to exhibit the provisions of Maintenance and Welfare of Parentsand Senior Citizens Act,2007(MWP Act) and its failure in protecting the rights of aged persons in India. Issues and challenges relating to implementation of MWP Act are discussed and solutions in the form of recommendation are pen down and attempted.
\end{abstract}

Keywords-Aged persons, social justice, pension, shelter, medical facilities and MWP Act.

\section{INTRODUCTION}

Political, Economic and Social Justice are the most extraordinary strengths of our Indian Constitution but in this $21^{\text {st }}$ Century these concepts have to be reinvented and researched. Especially the concept of Social Justice which the Constitutional framers thought was only about providing equal opportunities [1] but today has to focus on recent demands of the society i.e. the rights of Aged persons [2] to live with dignity. The Indian Constitution through Article 21, 39 and 41 i.e. fundamental right and direvtive principles of state policy do recognise few of the rights and concerns but the right to health, shelter, sustenance and dignity of aged persons is ignored or unforseen.[3] Globally several International Conventions[4] and declaration [5]have recognised significant human rights for the Aged persons[6] but because International laws are not mandatory and their implemntation is weak adherence to it has been ignored, violated and overlooked in many countries and India is no exception to it. Only the Apex Court through its numerous Precedents has given recognition to several rights and invented right to live with dignity [7] [8] [9] through is its interpretation under Article 21 of Constitution.[13]

\section{RESEARCH METHODOLOGY}

A purely analytical non empirical study is attempted by the researcher relying on significant precedents of Apex Court and books eminent authors.

\section{FINDINGS}

a. The Union of India through the Indira Gandhi National Old Age Pension Scheme has fixed

Revised Manuscript Received on April 22, 2019.

Dr. Ujwala Bendale, Assistant Professor, Bharati Vidyapeeth (Deemed to be) University, NEW Law College, Pune. India (E-mail: Dr.ujwalabendale@gmail.com)

Vidya Dhere, Assistant Professor, Bharati Vidyapeeth (Deemed to be)University, NEW Law College, Pune. India (E-mail: Namrata.dalvi68@gmail.com)
Rs.200per month for elderly person between age group 60 to 79 years and Rs. 500 per month for persons above 80 years of age.[10]

b. The Union of India, State Governments and Union territary adminstrtors has proved to be incapable in actively supporting the Indira Gandhi National Old Age Pension Scheme.

c. Inspite of Article 19(1)(e) and Article 21 of Indian Constitution and, Article 25(1)of UDHR and Article 11(1)of ICESCR expressely providing for minimum standards of living still the govrnment has been unsuccefull in providing minimum standards of livelihood to the poors and Aged persons. Right to live with dignity implies right to adequate shelter[11], food and clothing to the every person including elderly and but in our over populated country this is mere a dream.

d. The National Program for healthcare of elderly provided healthcare facilities to senior citizens but has not succeeded to the mark because they have not been fully operationalised in some districts of India.

e. The Maintenenance \& Welfare of Parents \& Senior Citizens Act, 2007 (MWP Act) came as a boon for aged persons which requires under Section 19 the State Government to establish and maintain at leastone oldage home in every distict in the coounry and Section 20 provides for medical support for senior citizens by the State Government.

f. MWP Act lacks its publicity, its awareness and advertising amongst the aged persons in rural and urban area. [12]

\section{CHALLENGES :}

a. The Pension Scheme and amount for elderly person is very inadequate and trivial to meet up the basic needs of survival.

b. The dawn for the Union of India, State Governments and Union territory adminstrators to work together for the proper implementations and planing of Pension schemes for Aged persons is yet awaited.

c. Right to shelter is subject to the economic budgeting by the State i.e the financial capacity of the State cannot be overlooked.

d. National Program for healthcare are not implemented effectively due to lack of coordination and cooperation between UOI, State Government and Union territary adminstrators. 
e. Every oldage home under Section 19 of MWP Act was to provide accomodation for 150 Senior citizens who are indigent but due to large popupation of indigent eldery the State is helpless to provide shelters to aged persons o live with dignity.

f. As the aged persons are unaware of their human rights guaranteed by Indian Constitution and MWP Act, its feasible for all to violate them.

g. Lack of Government support to the NGO's in spreading awareness leads to non publicity of rights of aged persons and also the MWP Act.

\section{ANALYATICAL RESULTS \& DISCUSSIONS}

a. Pension should be realistic and viable at least half the minimum wages so that the aged persons can sustain themselves with dignity.

b. Humanitarian approach is required on the part of Government of this country. Pension and Welfare Schemes can be implemented properly only if Union of India, State Governments and Union territory adminstrators stand together against corruption and wholeheartedly think for the welfare not only of Aged persons but also the poorest of poor in this country.

c. Revised Integrated program for Senior citizens should be implemented to encourage productive and active ageing.

d. Government must provide Grants for maintenanace of aged persons /senior citizens homes.

e. All National Programs for healthcare and overall development of aged persons must be implemented with due earnestness which is possible only if Union of India, State Governments and Union territory adminstrators genuinely decide to implement them.

f. Effective coordination between various ministers and Departments of State Government will ensure the welfare of aged persons.

g. Well planned publicity of the rights of aged persons under MWP Act will help the aged to live their remaining life with dignity.

\section{CONCLUSION}

Aged persons are vulnerable groups in the society and easily exposed to atrocities and exploitations. Aged people are not mere objects to be thrown or dumped, as they grow older they need good people to take good care but reality is very harsh and the Government of India and people at large should work hand in hand to erradicate the violtion of basic rights of aged persons. The Union Government must continuously supervise the working of State Governments and union Territories in spreading the awareness about rights of aged amongst the society, monitor the measures adopted for implementation of provisions of MWP Act and support in implementing the plan of action for the publicity of MWP Act.

\section{REFERENCES}

1. Jain, M.P., Indian Constitutional Law ( Lexis Nexis 2016).

2. Chandra, U., Human Rights (Allahabad Law Agency, 2017).

3. Justice A.D. Mane's, Lectures on Human Right. (Hind Law House ,2007)
4. UN General Assembly, International Covenant on Civil and Political Rights, 16 December 1966, United Nations, Treaty Series., UN General Assembly, International Covenant on Economic, Social and Cultural Rights, 16 December 1966, United Nations, Treaty Series.

5. UN General Assembly. (1948). Universal declaration of human rights (217 [III] A). Paris.

6. Anand, V.K., Human Rights (Allahabad Law Agency, 2003).

7. AIR 1981 S.C. 746.

8. (2016) 7 SCC 761.

9. Writ Petition (C) No. 193 of 2016.

10. WIKIPEDIA (July $7, \quad 2019, \quad 12: 30 \quad$ p.m.) https://en.wikipedia.org/wiki/National_Social_Assistance_Sch eme.

11. Right to Shelter: National and International Perspective- The International Research Journal of Social Sciences and Humanities Vol. 2(2) Feb. (2013) ISSN2320-4702. Supra note 9.

12. Sarda, M., Deshpande, B., Dharm, J., Dhere, V., Different aspects of environmental laws, International Journal of Recent Technology and Engineering, 2019

13. Sarda, M., Deshpande, B., Deo, S., Karanjkar, A comparative study on Maslow's theory and Indian Ashrama system, International Journal of Innovative Technology and Exploring Engineering, 2018

14. Sarda, M., Deshpande, B., Shringarpure, S., Smart city - Use of technology and the needed labor reforms, International Journal of Innovative Technology and Exploring Engineering ,2018 